
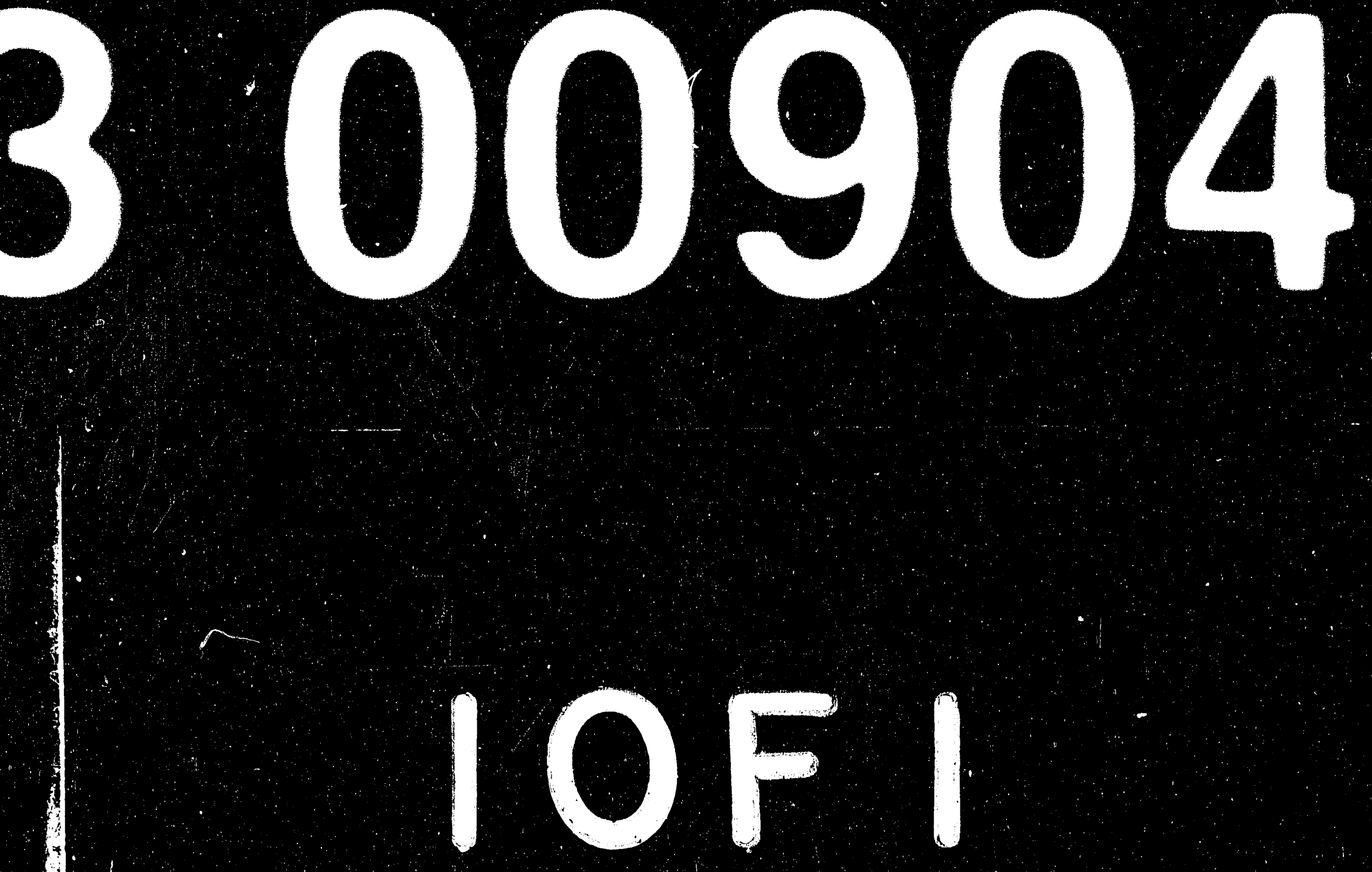

0

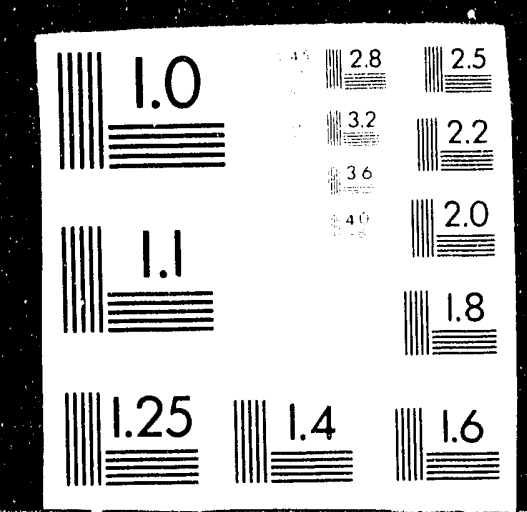




\title{
INDUSTRIAL MARKET RESEARCH REPORT \\ Feasibility of Commercialization of the \\ Advanced Antifouling Coating of \\ Copperlok, Inc. \\ October 1990
}

\author{
Prepared By \\ Associated Industries Corporation \\ Gregory J. Gormley, Author
}

\author{
Prepared For \\ Copperlok, Inc. Through A Grant From \\ Conservation and Renewable Energy \\ Inventions and Innovative Programs Office \\ U.S. Department of Energy \\ FGO/-89CE/5441
}

\section{DISCLAIMER}

This report was prepared as an account of work sponsored by an agency of the United States Government. Neither the United States Gnvernment nor any agency thereof, nor any of their employees, makes any warranty, express or implied, or assumes any legal liability or responsibility for the accuracy, completeness, or usefulness of any information, apparatus, product, or process disclosed, or represents that its use would not infringe privately owned rights. Reference herein to any specific commercial product, process, or service by trade name, trademark, manufacturer, or otherwise does not necessarily constitute or imply its endorsement, recommendation, or favoring by the United States Government or any agency thereof. The views and opinions of authors expressed herein do not necessarily state or reflect those of the United States Government or any agency thereof. 


\section{TABLE OF CONTENTS}

\section{CHAPTERS}

I INTRODUCTION

* Statement of objectives

* Description of Methodology

* Limitations of Study

* Conclusions and Recommendations

II INDUSTRIAL MARINE INDUSTRY

* Power Plants

* Pilings \& Bulkheads

* Buoys

* Off-Shore Structures

* Commercial Vessels

III RECREATIONAL MARINE INDUSTRY

* Boat Builder's

* Charter Fleets

* Marinas

IV APPENDIX

* References

* Interviews

* Surveys

\section{$\underline{\text { PAGE }}$}

1

3

4

5

6

7

11

19

21

23

25

27

36 


\section{ASSOCIATED INDUSTRIES CORPORATION}

MANUFACTURER'S SALES ENGINEERS MARKET RESEARCH \& SALES MANAGEMENT

November 1, 1990

Mr. Alexander A. Bosna

Ref: Transmittal Letter

Chief Executive officer

Copperlok, Inc.

25 Sunset Lane

Hatboro, PA 19040

Dear Mr. Bosna:

This letter of transmittal acknowledges the fulfillment of AIC's obligation to the objectives of our engagement as outlined in our Market Research Engagement Letter dated January $16,1989$.

Primary attention was directed towards those markets which presented the least "barrier of entry" based on your status as a start up organization with limited funds and confronted with crucial timing with regard to commercialization. This was done so that you would be able to develop the necessary business plans and formulate the required policies for success.

The industrial research performed concentrated on the economics of performance features as it relates to each market segment. AIC focused primarily on the boat builders, charter fleets, and marinas since those revealed to compose the prime commercial market.

AIC has performed primary and secondary research in three major areas, as it relates to your advanced coating system. There was secondary research performed to eliminate low valued markets and to confirm major market trends. The valuation of market segments was based on random sampling and direct survey techniques, as well as direct contact with valued experts in each market area.

We respectfully submit this report and feel that it will serve as the basis for your future requirements in the commercialization of your process.

Sincerely,

Gregory J. Gormley

President

GJG/sbg 


\section{INTRODUCTION}

The Copperlok antifouling process was initially designed to prevent marine growth on surfaces that are exposed to sea water. The process is a method of bonding thermally sprayed copper and copper alloys onto a specially formulated epoxy material that contains hollow spheres called microballoons. After the applied epoxy formulation cures, the surface is abraded so that the microballoons are fractured thus exposing a uniform microscopic, concave porosity in the prepared surface. The atomized thermally sprayed material is directed to the surface where it imbeds into the porosity in a molten state with volume and force so that the material fills the pores, bridges and then welds across the surface, creating a very thin laminate of the metal materials securely bonded to the bond coat and to the substrate.

The process was invented to address the needs of long-term antifouling. The current products in the marketplace have limited long-term effects, which last no longer tian several years at best and even then that performance is limited by the regional areas. 1

The Copperlok process brings together several different advanced techniques of composite technology and thermal spray technology to perform what ancient mariners realized, that the cladding of copper onto exposed sea water wetted surfaces can prevent biofouling for extended period of time. The Copperlok process laminates an approximate layer of coppernickel alloy $8 \mathrm{mills}(.008)$ thick to complex geometries with an expected active life of 15 to 20 years. The process achieves a quantum leap, within a performance ratio of 10 to 1 over current antifouling paints, while considering other alternative methods as bcing cumbersome and relatively difficult for production processing. 2

The best way to sum up the invention was done appropriately by Lars G. Soderholm, V.P. \& Editorial Director of Design News Magazine, when he made an award presentation speech to the inventors who had won the Grand Prize for "Best In Design" in the 1988 National Design News Contest. He stated that the process was "...ingeniously simplistic in design", and should prove to have "... numerous applications within numerous industries".

This study has been funded by the U.S. Department of Energy as a part of a much broader study to test and measure technical aspects of the process, as it relates to commercialization. Marine growth on the hulls of ships and boats creates drag and disrupts their flow. As a result, fuel consumption is substantially increased just to maintain 


\section{INTRODUCTION (CON't)}

speed. If optimum efficiency is required then increased maintenance costs are incurred. A truly long-term antifouling coating eliminates the vicious costs cycle. The economics of the process then has to be measured several different ways. First, is it truly less expensive than current paint and alternate methods and secondly, is the process perceived as viable and beneficial to the ultimate consumer in the highest potential market group.

This market research will not address the technical merits or aspects of it's design, that has been left to experts who are renowned for their expertise in mechanical engineering, as well as their knowledge of marine ecology. This report addresses the perceived acceptability of the process in several different marketplaces in the hopes of directing the invention to the most readily acceptable consumer group who will foster the demand for commercialization. 


\section{STATEMENT OF OBJECTIVES}

* Review the many different applications and market areas that appear to be favorable for business development. Investigate the financial resources required, necessary lead times, and "generic product recognition" that measure potential business success.

* Measure the opinions of "Key" markets and personnel that will identify the "Critical Path" which is defined as the path of least resistance to commercialization.

* Test the hypothesis that; "... the recreational boat industry is the primary market for initial product introduction".

* Identify major trends within the "Critical Path" market segments that will enhance or hinder the economic advancement of the business element.

* Quantify the business potential within the most favorable market niche and define a strategy for strategic alliances for efficient commercialization. 


\section{DESCRIPTION OF METHODOLOGY}

A general review and familiarization of the many different industrial applications for the process were studied. It was then agreed upon that a strategy be formalized to eliminate all but the most readily accessible applications and markets for commercialization.

In the preparation of this paper there were several different methods used to develop and gather primary and secondary information. In some instances it was to find an informative secondary resource (i.e. trade periodical) and confirm the findings with an expert in the field. In other instances, it was to find and interview the expert (i.e. trade organization executive) and ask for secondary resources as background information to substantiate the expert.

Finally, the chosen path was to zero in on a category within an industry segment and survey their knowledgeable opinions in the prospect of creating a profile on the group.

A "Critical Path Method" of IMR (Industrial Market Research) was chosen to target those few market areas that would foster the fastest commercialization potential and thus target one prime opportunity and eliminate those not so promising.

After those of the highest market potential were identified; then an in-depth, random, direct mail survey was utilized to develop demographic background information on the market group. Their perceived opinions were categorized to identify majority thinking on the product and it's performance capabilities.

Lastly, there were assumptions developed from the compiled information so that the profiles from the survey could be translated into business potential. 


\section{LIMITATIONS OF STUDY}

This study does not question the validity of the process from an engineering, mechanical or physical property perspective. Nor does it validate or substantiate any of the inventor's performance claims. It only addresses the potential popularity of the effect on commercialization based on the assumed fact that the process works as an effective long-term antifoulant and that the application process is economically feasible.

Therefore, this study will measure the popular demand based on the assumptions presented and the results derived from the surveys. This survey does not speak to the issue of price elasticity. The pricing assumption for all questions, in interviews and surveys, is simply "Would a $50 \%$ total cost savings in boat bottom maintenance (over a ten year period) justify an up front cost of 2 to 3 times that of a normal paint application?"

The selection of the Recreational Marine Industry, as the primary focus of the study, was based on Secondary source disclosure of laws and industry trends that clearly illustrate limited growth potential or extremely long lead time development requirements that would severely restrict progress toward commercialization. The secondary resources in most cases were confirmed with leading industry people who had direct knowledge of such limitations and confirmed the accuracy of the secondary source material.

The sources for random selection were based on the latest up to date industry information available at the time of the survey. The confidence level for reliability was tested to a 97\% (or better) level for each respective survey. Therefore, the surveys are representative of the populous to that level, respectful of the margin of error. 19

The opinion surveys were limited to the three coastal areas of the Atlantic, Gulf and Pacific regions. Therefore, the samples should not be extrapolated into a national profile. To the contrary, the make-up of similar boating groups within the interior U.S. have substantially different boating related concerns. 
The marine industry is undergoing major changes that will radically change the way marinas are operated in the next decade. The changes are favorable to a product like Copperlok, since a more corporate management approach is being implemented by corporations that own numerous locations where standardization is critical and return on investment is crucial.

The marina locations chosen for the initial commercialization should be one of those marinas that cater to the charter fleets, since the fleet operations people showed the highest interest level and could most readily perceive the operational economies. More than half of those fleet operators surveyed did not do their own antifouling work and relied on other marine contractors.

A marina location with full service capability that has a respected reputation for service and integrity in a populated boating area, that is located in a warm heavy biofouling region, is a primary prospect for a strategic alliance.

The surveys of the different segments of the marıne industry illustrate a vital need and keen interest in ail environmentally safe long-term antifouling coating system. If the Copperlok process is to make rapid market penetration, in any of the market segments, an environmental advantage has to be acknowledged and promoted.

The industry executives of organizations and private businesses are interested in sharing their knowledge and influence in promoting the Copperlok process. There should be an earnest effort to rekindle these contacts so that a business arrangement can be formed.

The best business format to follow in the marketing of the Copperlok process is that of a controlled franchise. This should be developed with the repair location that is chosen. Once the initial franchise program is developed, and the franchise program structured, the market viability will be very evident. The process has to be rendered to an active business.

Major trends within the Marine industry will foster the franchise concept. External demand and market forces will require a long-term antifouling system. The next two years will prove to be an incubation period to foster the required growth of the Copperlok Company. Competition is moving in that direction and it should limelight the Copperlok product as superior and more effective. 


\section{INDUSTRIAL MARINE INDUSTRY}

Initially, the industrial marine industry, for the purposes of this study, was composed of power plants, off shore structures, buoys, pilings and bulkheads. Ironically, each one of the categories within the industry was eliminated from detailed study since secondary research revealed that they presented either legal complications or they presented limited growth potential or they had extensive leadtime testing requirements. These barriers to market entry would preclude a small start-up entrepreneurial company like Copperlok, the opportunity to gain an immediate foot hold. Costly technical and legal lobbying would be required for even a well established and prosperous company to afford the expense necessary to fulfill compliance. 20

Electric power plant facilities that use sea water as a cooling medium are confronted with horrendous fouling problems. However, the majority of these facilities rely on the finding's of the Electrical Power Research Institute (EPRI) who has directed it's resources to the study and development of non-toxic and non-leaching coatings. Toxic antifoulant marine coatings were effective in controlling marine growth. The problem is that EPRI classifies copper alloys as a toxic antifoulant. The product endorsed by EPRI, such as the non-leaching, non-toxic silicone based materials are not suitable for all water conditions. The real misnomer is that the active antifoulant of copper, cuprous oxide, has been classified as toxic, along with organo tins based paints (TBT) that have been banned from stationary structures due to state and federal regulations governing the discharge of leachable, toxic material. 3

TBT based paiits have been banned from recreational boats and are only allowed to be used on military vessels. Copper and the cuprous oxide that leaches from recreational boat paint has been widely accepted as environmentally safe and is commonly used. The paradox to be resolved is to get copperlok accepted in those power plant locations where the material recommended by EPRI is not effective and get an acceptable classification for copperous oxide based materials. The use of copper in the Copperlok process does have EPA approval and is rejistered for use as an antifoulant. 4

In the instance of power plants, there are numerous applications where Copperlok can be employed effectively. Two years ago, Copperlok participated in a EPRI sponscred antifouling coating test. Coatings were classified into toxic and non-toxic. Copperlok had the highest periorma'ce rating and it was classified as toxic. Commercial success in this market will hinge on the possibility of reclassification or the slackening of the requirements necessary for approval. 
Industrial Marine Industry (Con't)

continue to investigate Copperlok as a solution to their unique problems and that the epidemic of the Zebra Mussel in freshwater lakes and rivers through out the Great Lakes area should investigate the potential of Copperlok as an alternative solution to their biofouling problem.

Pilings and bulkheads fall into a category similar to power plants. The state and federal legislation regarding discharge of leachable toxic materials regulates their use under the category of stationary structures. In this instance antifoulant coatings are prohibited and outlawed for use. The environmental reason for this is that most dock and bulkhead areas are confined. There would be a build up of the toxic material that could contaminate, at high levels, due to a lack of neutralization by tide flow. As a result, it is commonly acknowledged that wood preservatives that are not detrimental to the environment is the only coating or acceptable treatment allowed.

The U.S. Coast Guard operates and administers the Marine Aids tc Navigation System for the U.S. This system serves the needs of the maritime commerce, the general boating public and the Armed Forces. There are approximately 12 to 15 major commercial manufacturers of buoys producing more than 500 buoys per year. The standards for antifouling coatings that are used on wetted surfaces are regulated by the Coast Guard. Submission of a new antifoulant coating would have to be proposed by one of tile prime contractors of buoys. Critical types of fouling problems would have to be identified to propose a long-term antifoulant. Then a prime supplier would huve to incorporate the coating into the design that they propose. Assurance would have to be provided that proper testing had been performed and significantly documented to prove an openly exposed copper alloy coating, such as Copperlok, would not create excessive galvanic corrosion. Testing would be extensive and would have to be performed in paraslel between the contractor and the coast Guard Research and Levelopment Center. Coordination of the development would be expensive and lengthy. 5

Currently, buoys are serviced for marine growth every second year, with an annual inspection for location and damage. The normal overhaul cycle is six years. The wetted surface on an approximate inventoiy of 25,000. exposed (contact seawater) buoys is $1.4 \mathrm{million}$ square feet. The square footage presents an impressive market segment, however, the leadtime and required costs prove to be prohibitive at this time. 20 
Industrial Marine Industry (Con't)

The off-shore structure market of oil drilling platforms and associated structures has been an area where the majority of Copperlok's antifouling capability has been tested. Their work in conjunction with funded programs sponsored by Exxon, Conoco, and Norsk-Hydro have proven that the process is as effective as pure copper, which is the most effective, and yet resolves the costs and problems associated with sheet materials.

The problem with the domestic market is that it has been in a deep recession and the prcepec: for it to rebound is far into the future. The environmen .... concerns of drilling off the California coast has brought the development in that region to a standstill. Current forecast for the possible future development is 8 to 10 years at best. Development in the Gulf has plateaued. As a result, the production of oil drilling platforms has all but stopped. Domestic development of offshore reserves is limited to those production resources in place. The brightest hope in the industry is in the North sea, however, the prospect of enjoining another series of rules, cultures, and countries with different patent coverage is complex and would prove to be expensive. The immediate potential for this market is to contact the other oil companies that participate in off-shore development. The size of the market is limited, however, the continued availability of funded research may prove to identify other prospective opportunities that could develop a body of knowledge that could be used for commercialization in other markets. 20

Commercial vessels and the steel hulled fleets of tankers and freighters, as well as naval and pleasure fleets, present a huge market opportunity at first glance. The number of square footage for wetted surfaces is enormous. The problems confronted on the technical side prove to be just as enormous. The major concern with steel hulled ships is galvanic corrosion and cathodic protection. The problem is best summed up in the evaluation studies prepared in the preliminary screening for the funding of the project. It was noted in the, Evaluatiun of The Copperlok System by Dr. Dexter, " that an exposed area of raw steel would be sacrificed at a very high rapid rate when exposed to a much larger area of the more noble copper alloy". This area has to be studied and tested at length before commercialization is possible. 6

The costs and lead time necessary for such testing is far greater and time consuming than what could even be considered as a viable candidate for commercialization in the very near future. However, there are some promising notes to mention; there has beer considerable development of tough abrasion 
Industrial Marine Industry (Con't)

resistant epoxies that are currently being used on the hulls of ice breakers. If the fear of intimate contact between the two dissimilar metals is eliminated or reduced to the point where it could be controlled by conventional cathotic equipment and techniques, then this market presents a major opportunity. The one other concern that should be investigated when the technical questions have been resolved is the domestic availability of a facility to perform the work. Currently, the vast majority of new ships being built and repair work performed is being done overseas. The one significant difference, being work performed on U.S. Naval Ships. This could prove to be the most significant place to attempt to make inroads in an industry that is dominated by paint companies that do not look favorably upon a coating system that will last five times longer than their best performing paint. 
RECREATIONAL MARINE INDUSTRY

The recreational marine industry is confronted with tremendolis changes from just about every aspect of 1 ife that can impinge upon it. The boat building industry is consolidating into mega boat manufacturers, through acquisition and mergers. The small boat manufacturers are being pressured by the major OEM inboard and outboard enrine manufacturer's to exclusively secure their distributio:. channels. The concerns of environmental impact in the manufacture of boats is of major concern. The degree of VOC emissions allowed in different states and the continued demand for more regulation, not to mention the problems associated with insurance, financing and the general trends of the market and econrmy. There is an overall migration in consumer demands towaris the larger boat, which is putting pressure on the availability of dock space for the smaller boats. And then in turn, dock owner charge by the square foot rather then linear length. The problem of peolle buying boats only when the seller can provide dock space, is certainly an indication of the lack of available space and the relationship between the availability of dock space and the ability to sell boats. It appears that boat builders are not having an easy time of it, however, the prospects and trends for boat sales increase year after year as the demand for more boats incrfases. 7

Marina's, on the other hand, play an even more important role in the issues of public access to the waterways and in the demand for the sale of new boats. The denland for available dock space has increased. The value of real estate has escalated the highest in those areas where dock space is needed the most. Commercialization and development occur where shoreline waterfront availability is most needed. Conversely, that same increase in the value of real estate reduces the availability and access to a greater number of boaters. Tax valuations and waterfront property costs are continuously increasing based on "highest" and "best use" valuation rather than non-development property valuation methods. Thus, the "Mom and Pop" marina owner's, under tax pressures, sell out to land developers who turn the properties into expensive residential or commercially developed waterfront. As a result, the prior owners can make more on interest from the proceeds of the sale of the property then they could operating it as a marina business. The vast majority of marinas in the U.S. are privately owned (approximately 99\%). This is expected to change in the decade ahead as more development increases as a result of the obvious economic pressure. As the independent owner and operators dwindle, there will be an increased need for waterfront services and an efficient method of handing these needs. 
Recreational Marine Industry (Con't)

Marinas are also confronted with other pressures that will influence how they change. The most important of these will be state and federal laws regulating the environment and the development of waterfront property such as Florida and Connecticut. In states such as Florida and Connecticut Marina and boatyard spai:e is being lost faster than the development of new available docking space. Access to availabie slips increases the ability of a boat dealer to sell boats. There are pressures on the boat dealers to develop dry dock storage, as well as other alternate storage facilities, so that they will be able to continue to increase their sale of boats. 9

There are also other regulatory problems that are confronting coastal states, such as in the state of Delaware wher $\in$ there has been a moratorium on all marina permits until an acceptable plan is adopted sometime in 1990. Florida is working on a legislative proposal to limit the number of boats spaces based on a formula that would limit one boat per 100 feet of available shoreline. The state of New Jersey is taking a very aggressive posture with the removal and disposal of bottom paints. In particular, TBT and their requirements to license marinas and boatyards as a licensed pesticide paint remover. While still other states look towards the success of these regulations for possible implementation for waterfronts in their own state. These environmental questions are only compounded by the rules and regulations imposed by state and federal government regulators, by curtailing the maintenance dredging necessary within existing marinas. And yet again limiting the opportunity for the construction of new facilities without extensive environmental impact studies. The issues of public access to the waterfront and the need to increase marina slip capacity, will be two of the major issues confronting legislators, regulators and participants within the industry over the next ten years. 20-10

As a result of the major factors confronting marina operators they need to be supported and well financed. These are the factors that will require a more professional fully equipped marina operator and this is the reason for corporate interest in marinas as a major profit center. As the evolution of the marinas takes place the need for better products based on performance will be required. Marinas are standardizing much like the fast food industry of the $1950^{\prime} \mathrm{s}$. These corporate organizations will want to align themselves with superior products that can provide superior profits. 3 
Recreational Marine Industry (Con't)

Painting and scraping the bottom of a boat has to be one of the worst boatyard jobs and as a result it is profitable. state and Federal regulations will eventually curtail the practices associated with the process and require licensing for waste removal of hazardous materials. The market is ripe for a superior long-term antifouling process and franchising appears to be the best way to see it develop to it's maximum profitability. 18-19

Charter fleets fall into a unique position of being a subset of the marina industry that is directly effected by the pressures and trends confronting boat builders and marina operators. They are the largest identifiable group of professional consumers in the industry. Their roles vary and their category as charter fleet usually also includes marina operators or yacht brokers, however, they are the group that will recognize and capitalize on an economic opportunity. 17

Charter fleet operators responded overwhelmingly to the percej.ved advantages of a long-term antifoulant. The respondents had their fleet operations concentrated in the Florida-Caribbean region, which is known as to be a heavy biofouling area. They were impartial as to where they could obtain the copperlok coating system and were interested in getting more information. They could very readily identify that less service downtime equated to more charter time. This group was split between fleets using their own repair and maintenance locations and those contracting the services out to qualified repair centers. 
*

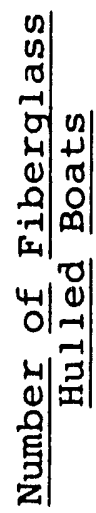

足



a

규

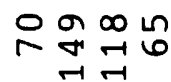

$\infty \infty \sim m$ rm $N$ oon तथ $r \rightarrow \infty N$
नَં

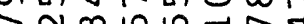

in.

NNOW

IOTINNT

ט $m m b m \& N m$ i n omara rora न 6 a $\mathrm{mm}$

Aं

$\sim$

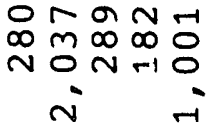

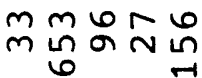

in mw 6000 in rN $\infty$ a $\infty$ mo $\infty$ in $m \forall \forall \forall \rightarrow m$ in N $\rightarrow M N N$ N

$060 \infty a$ ॠुळ minio $m m \rightarrow m 0$ $N$ in $m$
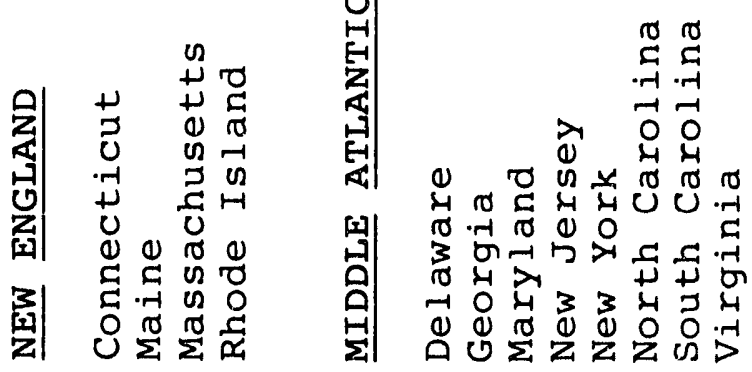

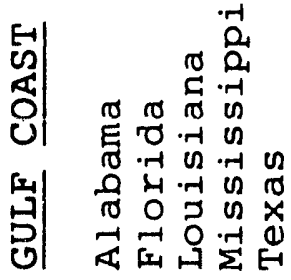




\section{*}

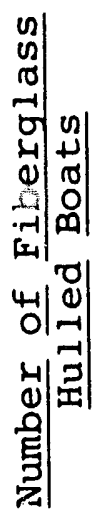

in

$\mathrm{m} m$ a

क

$\rightarrow$

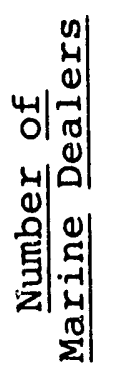

mon

in

$\infty N-$

טొ

ño

ams

in

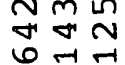

崩
응ํํ

mं

의

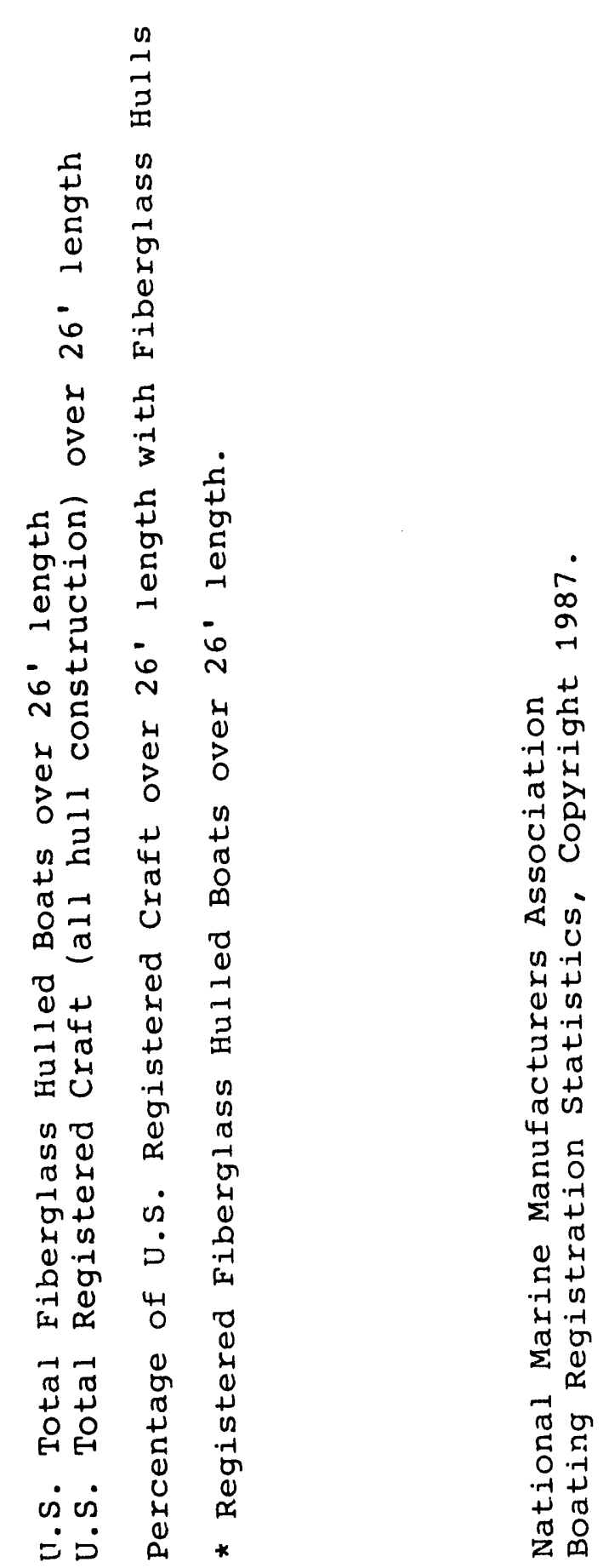




\section{MARINE INDUSTRY STATISTICAL SYNOPSIS}

\section{Comparative Responses}

\section{Boat Builders Charter Companies Boat Yards} CE NSM

$\begin{array}{lcccc}\text { Survey Size (Qty.) } & 55 & 55 & 54 & 175 \\ \text { Survey Response (Qty.) } & 18 & 10 & 19 & 30 \\ \text { Response (\%) } & 33.0 & 18.0 & 35.0 & 17.0\end{array}$

\section{$\underline{\mathrm{KEY}}$}

$$
\begin{aligned}
& \mathrm{CE}=\text { Chief Engineers } \\
& \mathrm{NSM}=\text { National Sales Managers }
\end{aligned}
$$



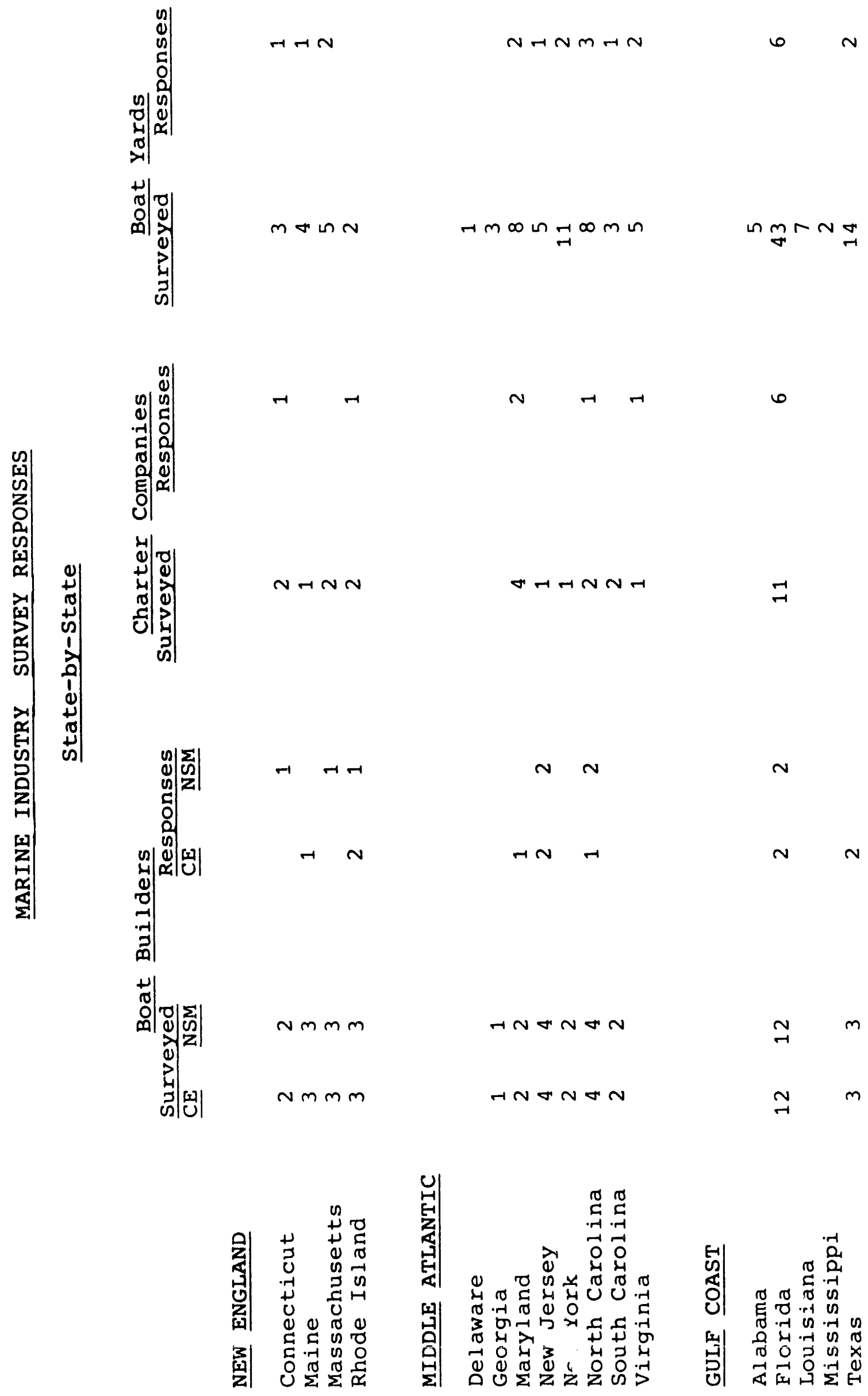

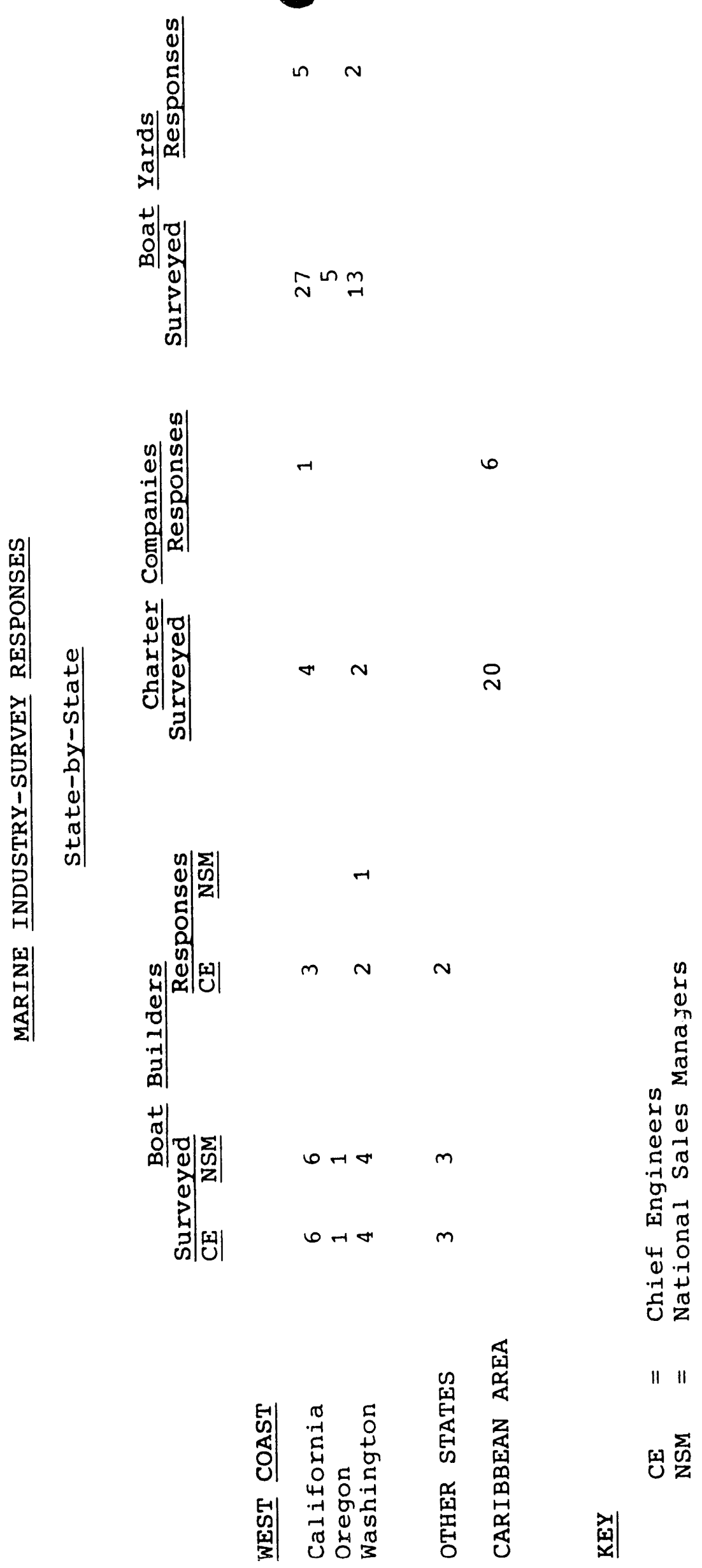
MARINE INDUSTRY SURVEY SYNOPSIS

BOAT BUILDERS

The population source for the survey was chosen from BOATING INDUSTRY, December 30, 1989, Volume 52, Number 13, "30th Marine Buyer's Guide " pp.109, Section IV "Stock Boat Directory"," ... Guide to Sail and Power boat manufacturers who build more than sixty boats ... annually for sale through qualified marine dealers." Names and addresses of headquarters, locations and key contacts by occupational title were crossed referenced to the following: Yachting, October 1989, Vol. 166, Number 4 "Boat Buyer's Guide 1990", pp. 77.

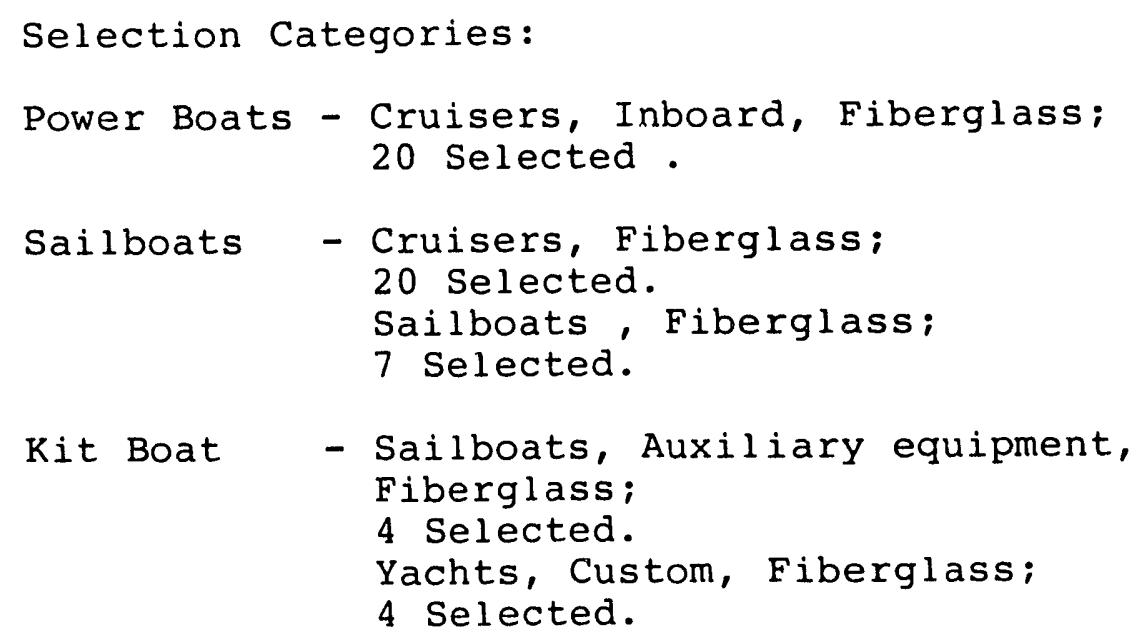

TOTAL SAMPLE SIZE: 55 Manufacturer's

The Chief Engineer for materials and processes and the National Sales Manufacturer of each boat manufacturer were surveyed for their opinions. The survey was identical for each group. The total survey for both categories was 110 surveys mailed. In this first category, there were 18 responses from the Chief Engineers, which represented $33 \%$ of the sample. Their were 10 responses from the National Sales Managers, which represented $18 \%$ of those surveyed. The average for both categories was a $25 \%$ response rate. 


\section{$\bullet$}

Boat Builder's $\left(\right.$ Con't $^{\prime}$

The following conclusions were drawn from the responses of the combined sample group:

* 69\% manufactured power boats - 32\% manufactured sail boats. The majority of the boats manufactured were in the 30 to 50 foot size range.

* $69 \%$ of the respondents provided antifouling paint at the factory as part of the production product. $30 \%$ providing the paint as part of the sale and $31 \%$ as a paid option. $68 \%$ being performed at the factory location and $17 \%$ at the at the delivery location. $38 \%$ of the Builders have a dedicated station in the production line process.

* $90 \%$ of the respondents felt chat long-term antifouling (10+ years) was a saleable benefit and $65 \%$ responded positively to a proposed "in-mold" process, (concerns were noted if changes in mold were not necessary and that the molds would maintain their current expected life).

* $75 \%$ would consider the exclusive purchase of an antifouling coating process if it would have a 10-year expected life.

* $60 \%$ felt an up front cost of 2 to 3 times that of a normal paint application was justified by the long-term benefits and most, $68.5 \%$, replied favorably to the cost being financed along with the initial cost of the boat.

* More than half of the respondents, approximately $55 \%$, felt that such a long-term antifouling coating should be handled as an aftermarket item. $63 \%$ of the sales managers had a positive response vs. $46 \%$ of the process engineers.

* $43 \%$ felt that the process should be limited to qualified "aftermarket" boat repair locations as a "franchised" operation.

* The overwhelming response of $68.5 \%$ felt that such a process would gain easier market acceptance at the OEM level if it were associated with a major resin or gel coat manufacturer. 
MARINE INDUSTRY SURVEY SYNOPSIS

CHARTER FLEETS

The population for the survey was chosen from CRUISING

WORLD, August 1989, Vol. 15, Number 8, pp.39, "World

Charter Listings". The selection was made randomly based on the headquarter location being listed as East Coast, Gulf Coast and West Coast. Although, headquarters listings did not coincide with actual fleet locations, respondents did indicate the major area for their fleet location.

Therefore, the responses can be correlated to a regional area. The service manager for each charter fleet was surveyed in order to solicit their responses as they related to their knowledge of the maintenance, as well as economic factors involved in the operation of their business.

The total sample size was 54 . There were 19 responses which equate to a $35 \%$ response rate. There are approximately 100 major charter fleets that operate in the three regional areas. Therefore, the survey covered just less than $20 \%$ of the population. The following conclusions were drawn from the responses of the sample group. Of those who did respond $100 \%$ either specified, recommended or influenced the use of antifouling materials for their respective fleet.

* The majority of the charter companies surveyed had 10 to 25 power and sailboats available, $90 \%$ of which are in the 30 to $50 \mathrm{ft}$. size range.

* $90 \%$ had sales, as well as repair facilities. $65 \%$ of these had their sales and service centers at one location.

* All respondents considered their charter areas to be a rapidly biofouling region and the respondents were equally divided between those who handled their own antifouling work compared to those who used outside contractors for this service.

* $80 \%$ of those who responded hauled out on an annual basis with $90 \%$ of the haul outs due to biofouling.

* 95\% felt that they lost at least one week, but no more than one month per year operational time due to biofouling. $85 \%$ felt their antifouling paint was effective for at least six months up to one year. However, $85 \%$ performed bottom cleaning of the hull in the event of haul out fo: any other maintenance reason. 
* The majoxity felt that minimum maintenance had to occur within a six morth period, such as scrubbing, water pressure cleaning, etc. The majority felt that regular maintenance and cleaning of the hull was necessary to extend the life of the antifouling paint beyond 12 months.

* $60 \%$ felt long-term $(10+$ years) antifouling was a benefit, while $30 \%$ felt haul out would still be required as often due to general maintenance and inspection.

* $80 \%$ perceived long-term antifouling as an operational benefit based on less maintenance time spent scrubbing the hull. $50 \%$ felt an up front cost of two to three times the cost of an annual application of paint justified long-term savings, while $25 \%$ felt it would not; $20 \%$ were unsure.

* Whether or not the long-term antifouling coating was purchased from the boat builder or a qualified repair location was immaterial. At present, $80 \%$ said they did not order their boats from the OEM boat builder with an antifoulant paint or coating applied.

of those charter fleets that were surveyed, the majority who responded had their base of operation in the Florida region and the Caribbean area. The corporate offices and mailing addresses were as diverse as Canada, Northeast and Mid-West U.S., as well as the southern regional area. 
MARINE INDUSTRY SURVEY SYNOPSIS

$$
\text { BOATYARDS }
$$

The population source for the survey was the mailing list services of Alvin B. Zeller, Inc., 37 E. 28 th Street, New York, NY 10016. The category selected was boat basins (Marinas); the total population in the US is 5,250 . Randomly selected, 1000 marina's were chosen as a mailing list in the following categories; Coastal States on the East Gulf and West Coasts of the US. Of the 175 surveys mailed out 30 responses were received. This represented $17.0 \%$ of the mailing. The respondents were evenly distributed throughout the coastal states, with the highest concentration of respondents correlating closely to the proportion of marinas in that state. The following conclusions were drawn from the responses of the sample group:

* $95 \%$ of the respondents had direct influence on the purchase or recommendation of antifouling materials for their respective boatyard. Of these facilities responding $88 \%$ cater to the racreational power boat, $65 \%$ to the recreational sail category and $41 \%$ to commercial boats.

* $92 \%$ of the yards responding applied antifouling paint and did fiberglass and gelcoat repairs along with a variety of other general maintenance services. Haul out capabilities, with $42 \%$ using the hoist/travel crane equipment, accommodated boats up to $30+$ tons in weight and $45+$ feet in length. All respondents had one form or another of haul out equipment. $45 \%$ of the boats maintained were under 30 feet and $35 \%$ of the boats maintained were in the 35-45+ size range. $85 \%$ of the marinas were open year round for boat bottom repair and antifouling paint preparation.

* 59\% of those responding considered boat bottom repair and preparation for antifouling painting, a major portion of their maintenance or repair business. While, the effectiveness of the longevity of the paint provided had mixed reviews as far as it's effective life. Most respondents, approximately $47 \%$ had mixed feelings over the proposal of a long-term antifoulant coating either as a benefit to the customer or to the operation of their organization. 


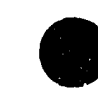

BOATYARDS (CON't)

* As a result it appeared that such a long-term antifoulant coating might be a threat to a major portion of their economic base. As a result frequent explanations were given that the coating would outlast the period of time that an individual would own his boat and that such a long-term antifouling coating did not exist.

* From a standpoint of customer service and satisfaction, boatyard operators were amiable to the idea of a longterm coating if in effect it were a proven product and there was customer demand for such a product then exclusivity of the licensing rights would be important based on a geographical area. Most respondents felt that there would be no economic gain as a result of being a franchise owner providing the exclusive coating. However, this can be explained in that no comparative income questions were drawn and the concentration was on service life of the product and perceived benefits by the customer. 


\section{REFERENCES}

1. Pouring on The Paint, Joe Caswell, Marine Industry, 1990.

2. Paint Removal and New Breed Antifoulants, Sven Donaldson, Professional Boat Builder, Octorbr 1990.

3. Protective Coatings for Cooling Water Systen in Southern Coastal Power plants, James B. Le Bleu, Journal of Protective Coatings and Linings, August 1990.

4. Tin-Based Paint Ban Sets A Dangerous Precedent, John Faks, Boating Industry Magazine, June 1989.

5. New Buoy Systems-Buoy Technology Survey, U.S. Coast Guard Research and Development Center, Groton, CT, 1989.

6. Evaluation of the Copperlok System for office of EnergyRelated Inventions, S.C. Dexter, University of Delaware, June 1988 .

7. A Long Term View of Boating Recreational Demand, Robert E. Moyat, National Marine Manufacturers Association, February 1985.

8. Push \& Pull of Marina Sell Outs, Neil W. Ross, Boating Industry Magazine, January 1989.

9. Mariners Become Environmental, Neil W. Ross, President, International Marine Institute, Boating Industry Magazine, May 1989.

10. Marinas-The Key To The Boating Industry's Future, Neil W. Ross, Boating Industry Magazine, February 1985.

11. The Marina, Neil W. Ross, IMI National Dockominium Conference, New Haven, CT, August 1987.

12. Let's Hear It For Mom \& Pop Marinas, Neil W. Ross, Boating Indus iry Magazine, April 1988.

13. Invest in Marina's? Wall Street Puzzled!, L. Scott Martens, Brandy Network News, Fall 1987.

14. 1990 Overview: The Marina Situation, Joe Caswell, Marine Industry, June 1990.

15. The Making of a Well-Equipped Marina, Joe Caswell, Marine Industry, August 1990. 


\section{References (Con't}

16. Boating Registration Statistics 1987, National Marine Manufacturers Association, 1988.

17. The Importance of the Recreational Marine Industry, National Marine Manufacturers Association, 1987.

18. Take The Franchise Test, Richland Poe, Success Magazine,

19. Marine Industry Survey, G.J. Gormley, Associated Industries Corp., October 1990.

Survey Population Comparative Statistics

Survey Statistical Synopsis

State By State Survey Responses

Boat Builders Survey Responses

Boat Builders Survey

Boatyard Survey Synopsis

Boatyard Survey

Charter Fleet Survey Synopsis

Charter Fleet Survey

20. Marine Industry Interviews - G.J. Gormley, Associated Industries Corp., October 1990.

Ronald Stone, Director of Government Relations, National

Marine Manufacturer's Association.

Edward Swikart, Jr. Executive Director, N.J. Marine Trades Association.

George Gilmour, President, Main Ship Corporation.

Philip I. Abrams, Off-Shore Structures Division, Exxon Production Research Company.

Rick Walker, Senior Ocean Engineer, U.S. Coast Guard $\mathrm{R} \& \mathrm{R}$ Center. 
Mr. Ronald Stone

Director of Government Relations

Interview

National Marine Manufacturer's Assoc.

Washington office

100 Thomas Jefferson Street N.W.

Washington, DC 20007

Mr. Stone is the Director of Government Relations for the NMMA. He is also the National Director of Boating Facilities Development Department of the NMMA. Along with these prestigious and responsible positions, he also holds a Secretarial post with the National Water Access Coalition that is also located in Washington, D.C.

Initially, I asked Mr. Stone to comment on the importance of marinas. Why is the boat building industry placing such tremendous focus on the marina? His responses were as follows. He mentioned that there is tremendous changes occurring within the boating industry and a lot of those changes are the result of factors both economic, environmental and governmental directed towards the marina location. He mentioned that "... in essence the growth of the boat industry will be dependent upon the ability of marinas to expand through an evolutionary process that are effected by major forces within the marketplace". He mentioned that organizations are being formed so that representation of the varying interest groups within the marina segment will be able to "live together and share the waterfront". Hs: mentioned that NMMA had just recently formed a special department to coordinate the interests of the different factions, government, boat builders, marinas and other groups that rely on the marine industry for a living. This was in response to the needs to transfer information and maintain an open dialogue with all the different parties.

Mr. Stone had the opportunity to review a series of articles and literature on the Copperlok process. His comments were that the Copperlok process appeared to be "environmentally right on". He mentioned that environmental concerns are the biggest issue and the affect they have on the diminishing availability of waterfront property and the loss of this property to more commercially viable projects. "The window of opportunity", that he sees for the product, is to focus on the "environmentally safe" aspects of the process. 
Mr. Ed Swikart, Jr.

Interview

Executive Director

N.J. Marine Trades Association

90 Monmouth Street

Suite 303

Red Bank, NJ 07701

Mr. Swikart was contacted as a result of an extensive conversation with Mr. Ronald Stone, who is the Director of Government Relations for the National Marine Manufacturer's Association. Prior to the interview, there was a compliment of magazine articles on the Copperlok process, as well as the a compliment of Copperlok literature sent to Mr. Swikart for his review so that he could be current with the process prior to the interview.

Mr. Swikart, being actively involved as the Executive Director of the N.J. Marine Trades Association, was extremely knowledgeable and conversant on topics that would directly effect the commercialization of the Copperlok process. One of topics covered was that future prospect of the boating industry and marinas in the state of N.J. He felt that N.J. had an extremely promising future in the growth of the marine trades industry. He felt that there were some major trends taking place and that there were commercial as well as political topics that had to be addressed in the very near future in order to maintain the projected level of growth.

The topics mentioned that would be necessary to foster growth was an increased participation on the part of both government and individual marine owner/operators in increasing the availability of access, as well as the number of boat slips. He felt that there was tremendous pressure both

environmentally and economically on what he attributed to a "shrinking shore line." As a result he mentioned that marine operations would have to become more economically stable in order to ward off what he considered the impact of private developers limiting the access to the shore and reduction of boat slips as a result of commercial condominium and townhouse development, as well as the proliferation of dockominiums. He felt that there was a need on a political basis within each and every state and in particular N.J. to assess the taxable value of marina properties at their present value as boatyards rather than an excessive rate which would be based on the highest use value. He also noted that there is more of a business oriented "take over" in marinas at this time. As a result, a lot of the so-called "Mom and Pop" type of boatyards are going out of business because "they can make more interest on the proceeds of the sale of the property than running it as a business. 
Swikart Interview (Con't)

Consequently, the business oriented marina makes basic business decisions as to the best potential for the property and as such there has been an enormous development in dockominiums, as well as permanent development on areas that were formally boatyards, and as a result limits the access or the availability of the total number of boat slips.

He felt that the Copperlok process had great promise, if in fact it would meet the performance level that is presented in the literature and that the current trends within the marketplace persisted. He felt confident that the trends would persist, however, as far as a marketing approach he was adamant that the process should be proven out at a local marine location that has a high reputation for boat repair and maintenance. As a result of gaining working knowledge of the process with a reputable marina, the prospect for selling the process as a licensed program or franchise would be the most successful.

He suggested that Copperlok speak with several major boat repair centers, who are members of his organization, as well as several major boat manufacturer's within the N.J. area in order to get a better feel for market acceptance. He also felt that the introduction of such a process would be more readily accepted, and the economies of the process most readily realized if in fact the initial testing of the "boatyard concept" were performed in the Florida region where fouling is a persistent 12 month out of the year problem.

He felt that the Copperlok process would be most readily accepted in the marketplace, if it could be proven that it is more environmentally sound than current paint methods. Either from a maintenance point of view for land based marinas or from an actual in water use measuring the leeching or activation of the potent elements of the antifoulant. He said that in the near future there is a concern as to whether copper will be banded much like TBT. He did not know of any pending legislation or action in that direction. He did mention that environmentalists are looking for a more passive solution to the concern of antifoulants. Environmental impact is critical in today's marketplace and it will increase with intensity in the coming years. Currently, New Jersey legislators are considering the formulation of a bill that would license qualified repair centers for the removal and disposal of bottom paints. New Jersey would be the first for such legislation, however, Connecticut, Massachusetts and California would not be far behind. 
Mr. George Gilmour

Interview

President

Main Ship Corporation

Vanderburg Road

Marlboro Industrial Park

Marlboro, NJ 07746

I had the opportunity of interviewing Mr. George Gilmour in regarding the commercialization of Copperlok's long-term package of promotional literature and was familiar with the process prior to the interview.

In his opinion, if a long-term antifoulant can be cost justified for the after market then it has commercial potential. However, he does have some reservations regarding it's cost effectiveness in a boat builders production process.

His main concern is that the process would have to be cost effective from the standpoint of the customer, and from the boat builder's ability to apply the process in his own shop. Therefore, time and money come into play in regards to the application of the process. Would it be "in line" or would it be a "final" production process or would it be "labor intensive" like a two tone gel coated hull which has been all but eliminated in the industry. His current production sequence applies antifouling coating right after the hull has been pulled from the mold and the bottom has been prepped to clean off the mold release agents. As a result, it is one of the first steps in the process and it is done so that hull and bottom paint cure prior to other fabrication in what they consider the fiberglass molding building.

He visualizes the Copperlok process, as being one which would require a separate building. It could not be done in the fiberglass work area where an open flame is not allowed. The fiberglass work area is a fire hazard because of the extremely high level of combustible styrene fumes. Local permit and insurance rules and regulations prohibit any type of open flame as an imminent hazard. In order to comply he would have to build a building or perform the coating last, possibly outside, to make it competitive, which he felt was limiting.

In summary, he stated, "it would be a hard sell for him to buy off on the prospect that such efforts would be cost justifiable to the boat builder",... who follows similar production process steps as his company. 
Mr. Philip I. Abrams

Interview

Materials Section

off-Shore Structures Division

Exxon Production Research Co.

P.O. Box 2189

Houston, TX 77252

Mr. Abrams was contacted because of his knowledge of offshore structures and because of his continued work in the application of the Copperlok product on Exxon off-shore structures. To date, Copperlok has had several projects with the Exxon Production Group that have been directed to several different areas of the off-shore structure. Those notably being the node sections where the critical weld areas of the structure are joined, and the splash zone where biofouling is greatest. It is in these structural areas of the platform that the affects of side loading stress are compounded marine growth. Therefore the limitation of marine growth in these areas extends the working life of the structure and eliminates the cost associated with routine maintenance and the ability to down size the structures design. He mentioned that the focus of his projects have been in the regional areas of the Gulf of Mexico and the California coast. These two areas present heavy biofouling to the structures in those regions.

He thinks highly of the Copperlok process because of the ability to cover complex geometric surfaces which in effect are the node areas or the weld areas of the structure. The Copperlok process is an excellent antifouling material.

However, he has concerns regarding the ability to handle the finished product since the coating has to be very abrasion resistant. He stated that " the process does have very good potential to be automated and as a result can be very cost effective in coating not only the node areas, but long lengths of structural pipe". He mentioned that there are several competitive products that have been investigated where copper materials are coated or imbedded in a rubber mat, which in effect provides a cushioning effect and eliminates the prospect of damage due to abrasion. The other products, however, do not have the price performance or the ability to cover complex geometric areas and are somewhat cumbersome in installation. He did mention that one limiting factor of the Copperlok process is that it can only be applied to new structures prior to service. He also mentioned that his company at this time is not building, nor do they have plans to build many structures in the near future. Copperlok's economic niche is that it's coating would reduce the steel required in the design of a structure. Thus reducing the production cost of the platform. 


\section{•}

Abrams Interview (Con't)

He felt that one area of development, which will be investigated in the near future, is the potential of increasing the thickness of the Copperlok coating. He currently feels that 8 to $10 \mathrm{mils}$ of the copper-nickel layer will be effective for 15 to 20 years. He mentioned that when they design off shore structures the expected life is 20 to 40 years and that maintenance during the course of it's life is critical. Therefore, the increased thickness of the initial application of Copperlok should coincide with the expected life of the platform.

He did not feel that there was a great market potential for Copperlok with his organization since there are few plans for new structures. He did mention that there are future plans for off-shore production for California, however, his organization was looking at a lead time of ten years before they would actually have the opportunity to go into production. He mentioned that the off-shore drilling segment of the oil industry has been in a recession for the last eight years and it's recovery was still in the distant future. He noted that Copperlok, as an organization, should participate in more industry oriented promotions, such as major trade shows and advertising in the trade publications. He did mention that he does plan to write a paper based on the last project that was done with Copperlok. The paper, with photographs, would be presented at The off-Shore Technical Conference in Houston, TX in May of 1991. He felt strongly that Copperlok should participate in the conference by exhibiting and presenting their own paper. His organization plans to continue development work with the Copperlok organization, however, Copperlok should approach other major oil companies in the off-shore market and that he would be more than willing to share his findings with those organizations in the hopes of promoting and developing business for Copperlok. 
Mr. Rick Walker

Interview

Senior Ocean Engineer

U.S. Coast Guard Research \& Development Center

Avery Point

Groton, CT 06340

prior to the interview, Mr. Walker was sent a complete compliment of magazine articles and literature on the Copperlok process. Several weeks thereafter, he was contacted for this interview. He did take the time to review the information and found it extremely interesting and as a result, had the following information to relate to the interviewer.

The United States Coast Guard operates and administers the Marine Aids to Navigation System for the United States. This system serves the needs of the maritime commerce, the general boating public and the Armed Forces. An aid to navigation is "any device external to a vessel intended to assist a navigator in determining his position, a safe course, or to warn him of dangers or obstructions to navigation". Thus a buoy.

Nationally, the Short Range Aids (SRA) system is comprised of over 50,000 aids to navigation platforms. Half of which are buoys. The size of the buoys used in the system range from $1 \mathrm{ft}$. in diameter, weighing less than $100 \mathrm{lbs}$, to 40 ft. in diameter and weighing 100 tons. A principal

distinction between buoy types is whether they are lighted or unlighted. This is generally a substantial demarcation in terms of the buoys complexity, cost and required maintenance. The Coast Guard maintains approximately 4,155 lighted buoys and 21,830 unlighted buoys in the SRA system.

There are approximately 12 to 15 commercial manufacturer's of buoys that produce in excess of 500 or more buoys per year. There is approximately $1.4 \mathrm{million}$ square feet of wetted surface on the total inventory of the SRA. $10 \%$ of the inventory is in rotation to dry dock at any one time.

The normal time on station between removal for servicing will vary with the location ("exposed" - located in the sea water) and the importance of the location to navigation. The two year normal inspection and servicing with a buoy tender is standard procedure. In this inspection process the work is normally done on the deck of the buoy tender and overall maintenance and servicing, such as bottom maintenance, is performed. The relief cycle, which is the period of time between total overhaul, is performed normally within a six year period. Each buoy within this system is visited annually and checked for position, as well as possible replacement. 


\section{Walker Interview (Con $\left.{ }^{\circ} t\right)$}

He mentioned that our best prospect of getting an antifouling coating on any part of the system would be to go to those proven contractors, who are currently major suppliers to the U.S. Coast Guard. With these proven sources, coating samples would have to be submitted for life cycle testing, as well as possible galvanic incompatibility with the current design. As a result, the potential for galvanic corrosion would have to be tested, as well as the engineering design of the mooring shackle itself would have to be investigated so that dissimilar metals would be isolated.

He thought that the Copperlok coating system did have promise and he did mention that currently there was a major effort to redesign the entire SRA buoy system. The main objective of the program is to extend the longevity and reduce the cost, maintenance and service. He mentioned that the best approach should be directing attention to the buoy manufacturers since currently the Coast Guard is surveying these different organizations to solicit their ideas for all possible avenues of improvement. 


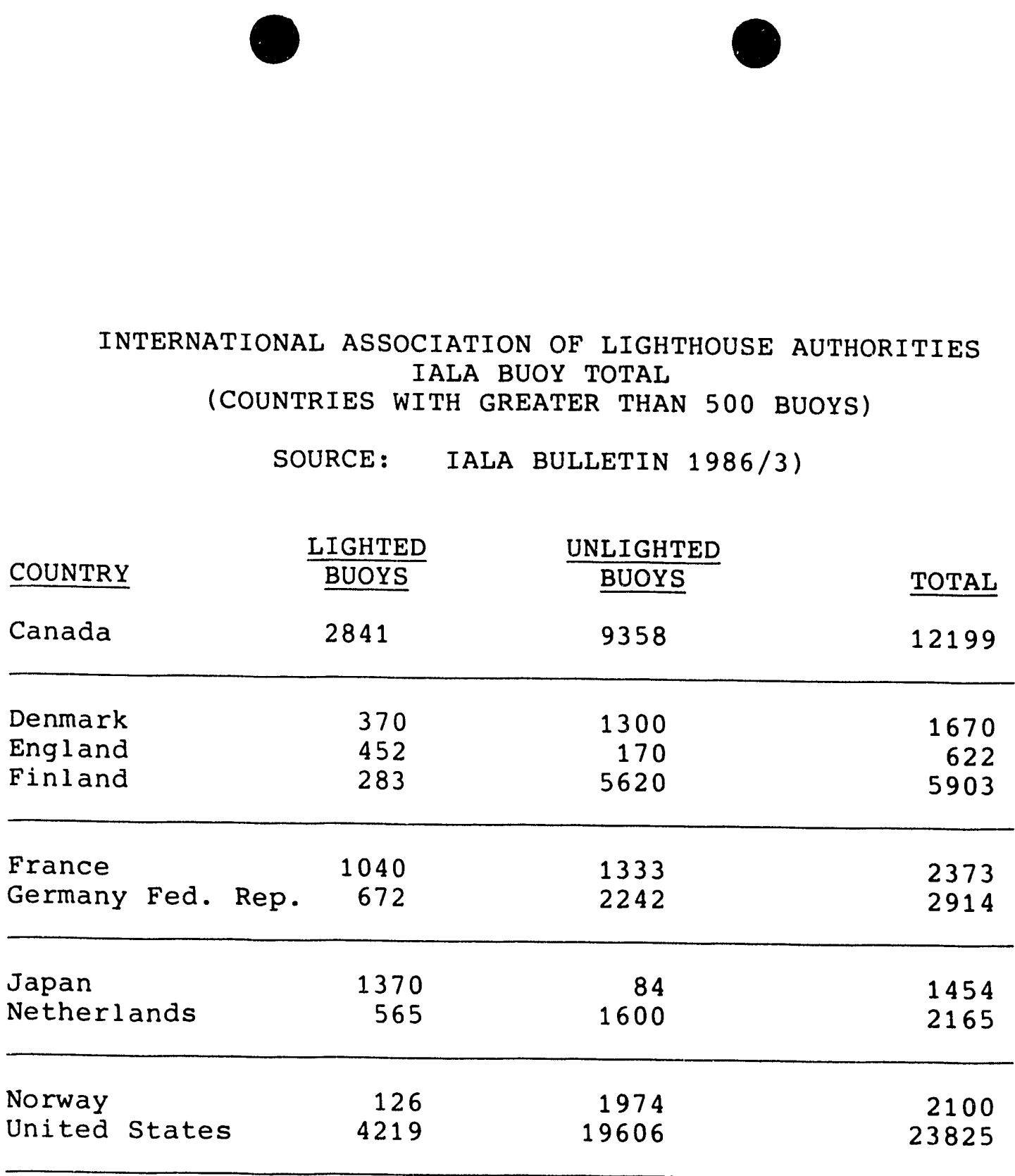

* $10 \%$ to $20 \%$ estimated in drydock storage inventory.

$$
\text { U.S. COAST GUARD }
$$

Lighted and Unlighted Buoy Population By Environment

Environment $\quad \underline{\frac{\text { Number }}{\text { ighted }}} \frac{\text { Of }}{\text { Buoys }} \quad$ Unlighted Buoys

\begin{tabular}{lrr} 
Exposed * & 1620 & 1380 \\
Protected/Semi-Exposed & 1780 & 9050 \\
Fresh Water with Ice & 700 & 1970 \\
Rivers & 55 & 9430 \\
& & \\
\cline { 2 - 3 } Total: & 4155 & 21830
\end{tabular}

* Located in Sea Water Areas 


\section{ASSOCIATED INDUSTRIES CORPORATION}

MANUFACTURER'S SALES ENGINEERS MARKET RESEARCH \& SALES MANAGEMENT

Apri1 4, 1990

SURVEY I - Chief Engineer Materials \& Processes

Dear Boat Builder:

AIC has been commissioned by an advanced coatings company to survey OEM - Recreational Boat Builders as to the commercial feasibility of a "new" and "advanced" long-term antifouling system; The survey is part of a grant from the U.S. Department of Energy to analyze energy savings as it relates to the flberglass hull of recreational boats.

The antifouling coating system will last in excess of ten years. It is not considered a toxic pollutant and would be approved as environmentally safe. The economic savings to the boat owner could be as much as 508 over current paint methods within a ten year period. The boat manufacturer would have the opportunity to "sel1" the process as an option to their customers.

Your answers will be used for statistical tabulation only. Neither you nor your company will be identified. Your answers will provide vital information that will be critical in the determination of its commercialization.

Please complete and return this questionnaire as soon as you can. A postage paid envelope 18 included. If you have any questions, please feel free to contact me directly.

Sincerely,

Gregory J. Gormley

president

GJG/ef

Enclosure 
OEM - Recreation Boat Builders Survey

SURVEY I - Chief Engineer Materials \& Processes

\section{BACKGROUND INFORMATION}

Survey Participants Name

Title

1. What type of boats do you manufacture?

Power $62 \%$ Sail $38 \%$

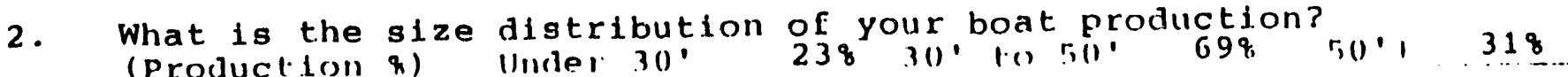

3. Do you currently provide Antifouling Paint or Coatings with your production product?

YES $\quad 698$ NO $\quad 8 \%$

If YES, Inclusive with order 318 Customer Paid Option 318

If YES, what percentage is performed at each location?

Factory 628 Delivery Location 158 other 08

4. If Antifouling Paint is applied, is it applied at a dedicated station in the production 1 ine process?

YES NO

5. Is the Antifouling Paint or Coating applied prior to final preparation for transportation or launch?

Transportation $\quad 548$ Launch $\quad 318$ Niether

\section{PRODUCT SURVEY}

6. Do you, as an OEM-Boat Builder, perceive long-term antifouling $(10+$ years) as a benefit?
YES 778
NO 158
Explain

7. Would an antifoulant coating with little or no maintenance be a saleable benefit to your buyer?
YES 778
NO
$0 \%$
Explain 
8. Do you perceive all "in mold" process, as a benefit to the oEM Boat Builder, as an opportunity for "add-on" business in the sale of the boat and future service?
YES 628
NO 158
Explain

9. Would you consider the purchase of an exclusive long-term antifouling coating process that would last in excess of 10 years in service?
YES 629
NO $158 \ldots$ Fxplain

10. Would a 508 total cost savings in hoat hottom maintenance fiver a ten year perind) justify an up rront eost of $2,1,3$ limes that of

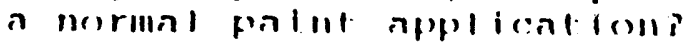

YFS $38 q \ldots \quad N() \quad 38 q$ Fixplinin

11. Would the up front cost of a long-term antifouing coating appeal to your customers if those costs were included in the $\vec{r}$ inancing of the boat?
YES 628
NO $\quad 88$
Explain

12. Do you think that long term antifouling coatings should be handled as an aftermarket item?
YES 468
NO 318
Explain

13. Do you think that a long term antifouling coating would gain easy market acceptance, at the OEM level, if it were associated with a major resin or gel coat manufacturer?
YES
NO 158
Explain

14. Do you think that such a process should be limiled to the aftermarket customer if presented as a franchise operation at quality boat repair locations?
YES
$\mathrm{NO}$
$548 \quad$ Explain

THANK YOU 'ERY MUCH! !! 


\section{ASSOCIATED INDUSTRIES CORPORATION}

MANUFACTURER'S SAI.ES ENGINEERS

MARKET RESEARCH \& SALES MANAGEMENT

April 1, 1990

SURVEY II - National Sales Manager

Dear Boat Builder:

AIC has been crmmissioned by an advanced coatings company to survey OEM - Recreational Boat Builders as to the cummercial feasibility of a "new" and "advanced" long-teril antifouling system.: The survey is part of a grant from the U.s. Departinent of Energy to analyze energy savings as it relates to the fiberglass hu', of recreational bots.

The antifouling coating system will last in excess of ten years. It is not considered a toxic pollutant and would be approved as environmentally safe. The economic savings to the boat owner could be as much as 50 s over current paint methoos within a ten year period. The boat manufacturer would have the opportunity to "sel1" the process as an option to their customers.

Your answers will be used for statistical tabulation only. Neither you nor your company will we identified. Your answers will provide vital information that will be critical in the determination of its commercialization.

Please complete and return this questionnaire as soon as you can. A postage paid envelope is included. If you have any questions, please feel free to contact me directiy.

Sincerely,

Gregory J. Gormley

Presianent

GJG/ef

Enclosure

$-39-$
P.O. Box 69()$\cdot$ Newtown. Pennsylvania 1894().(1690) $\cdot(215) 86(1) \cdot 8998$ 
OEM - Recreation Boat Builders Survey

SURVEY II - National Sales Manager

BACKGROUND INFORMATION

Survey Participants Name

Title

1. What type of boats do you manufacture?

Power $75 \%$ Sail 258

2. What is the size distrihution of your hot production?

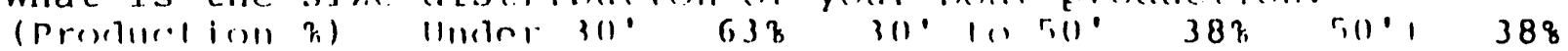

3. Do you currently provide Ant ifouling paint or coatings with

your production product?

YES $13 \%$ NO $\quad 258$

If YES, Inclusive with Order _ 508 Customer Paid Option 258

If YES, what percentage is performed at each location? Factory 758 Delivery Location ...388 other

4. If Antifouling Paint is applied, is it applied at a dedicated station in the production 1 ine process? YES $\quad 38 \%$ NO 508

5. Is the Antifouling Paint or Coating applied prior to final preparation for transportation or launch?

Transportation $\quad 638 \quad$ Launch 508 Niether

\section{PRODUCT SURVEY}

6. Do you, as an OEM-Boat Builder, perceive long-term antifouling $(10+$ years $)$ as a benefit?
YES
$100 \%$
NO
Explain

7. Would an antifoulant coating with little or 110 maintenance be a saleable benefit to your buyer?

YES 898 NO 138 Explain 
8. Do you perceive an "in mold" process, as a henefit to the oEM Boat Builder, as an opportunity for "add-on" business in the sale of the boat and future service?
YES $63 q$
NO 388 Explain

9. Would you consider the purchase of an exclusive long-term antifouling coating process that would last in excess of 10 years in service?
YE.S
898
$N(1) 138$ Explain

10. Would a 50 s total cost savings in boat bottom maintenance lover a ten year period) justify an up front cost of 2 to 3 times that of त normal painl application?

YES 758 No 258 Fixplinin

11. Would the up front cost of a long-term antifouling coating appeal to your customers if those costs were included in the financing of the boat?
YES $75 \%$
NO 258 Explain

12. Do you think that long term antifouling coatings should be handled as an aftermarket item?
YES 638
NO 388 Explain

13. Do you think that a long term antifouling coating would gain easy market acceptance, at the OEM level, if it were associated with a major resin or gel coat manufacturer?

YES 758 NO 258 Explain

14. Do you think that such a process should be 1 imited to the aftermarket customer if presented as a franchise operation at quality boat repair locations?

YES $38 \%$ NO $63 \%$ Explain

THANK YOU VERY MUCH ! !

$-41-$ 


\section{ASSOCIATED INDUSTRIES CORPORATION}

MANUFACTURER'S SALES ENGINEERS

MARKET RESEARCH \& SALES MANAGEMENT

April 2, 1990

Dear Service Manager:

AIC has been commissioned by an advanced coatings company to survey Recreational Charter fleets as to the cominercial feasibility of a "new" and "advanced" long-term antifouling system. The survey is part of a grant from the U.S. Departinent of Energy to analyze energy savings as it relates to the biofouling of recreational boat hulls.

The antifouling coating system will last in excess of ten years. It is not considered a toxic pollutant and would be approved as environmentally safe. The economic savings to the fleet owner could be as much as $50 \%$ over current paint methods within a ten year period. The operating efficiencies that could be achieved would be the direct result of a continuously clean hull.

Your answers will be used for statistical tabulation only. Neither you nor your company will be identified. Your answers will provide vital information that will be critical in the determination of its commercialization.

Please complete and return this questionnaire as soun as you can. A postage paid envelope is included. 1.f. you have any questions, please feel free to contact me directly.

sincerely,

Gregory J. Gotinley

president.

GJG/ef

Enclosure

\section{$-42-$}

P.O. Box 69() • Newtown. Pennsylvania 18940-(069) • (215) 860-8998 
Recreational Charter Fleets Survey

\section{BACKGROUND INFORMATION}

Survey Participants Name

Title

1. Do you specify, recommend, or influence the purchase and use of antifouling materials for your fleet? YES $100 \%$ NO

2. What type of boats ro youl linve nuailable for elinterer? power. 638 Sin 1.898.

3. What is the size distribution of your charter fleet?

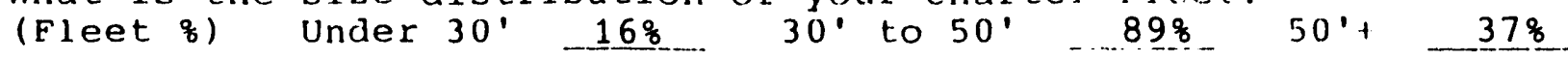

4. What is the approximate number of boats available for charter? under $10-58 \quad 10$ to $25-53826$ to $50-21850+-168$

5. How many base locations do you have? (i.e., sales and maintenance-repair centers).

Charter Sales $\quad 89 \%$ Repair $\quad 848$ Sales \& Repair 638

6. Do you service your own fleet for antifouling work or do you use the services of contractors?

Own Facility $58 \%$ Contract facility $58 \%$

7. Does your fleet cruise in what is considered a rapid biofouling area or region?

YES NO

8. How often does your fleet receive what would be considered routine maintenance that would require haul out? Twice/year - 5\% Once/year - 79\% Less than once/year - $11 \%$

9. Is haul out normally required as a result of hiofouling? YES $\quad 89 \%$ NO $5 \%$

10. If haul out is required for reasons other than biofouling is bottom cleaning and hull maintenance performed? YES $84 \%$ NO $16 \%$

11. What percentage of haul out would you attribute to biofouling or biofouling related problems? $84 \%$ 
12. How much time annually is a boat of your flect not. operational as a result of biofouling? $95 \%$ one month $+1-$

13. What is the average length of time that you consider your antifouling paint effective before a minimal type of maintenance is required (i.e., scrubbing, water pressure cleaning)? 6 months - 538 6-12 months - 32\% 12 monthst - $5 \%$

14. What is the average length of time you consiler your antifouling paint effective before the hull has to be cleaned and repainted? 6 months - $11 \%$ 6-12 months - 32\% 12 monthst - 53\%

\section{PRODUCT SURVEY}

15. Do you perceive long-term ant ifouling (101 yours) as i hellefit? YES $63 \%$ NO $32 \%$ Fisplin

16. Would an antifoulant coating with little 0 , maintenance be an operational benefit to your organization?
YES
798
NO
168
Explain

17. Would a $50 \%$ total cost savings in antifouling bottom maintenance (over a 10-year period) justify an up front cost of 2 to 3 times that of a normal paint application? YES $\quad 478$ NO $26 \%$ MAYBE $21 \%$

18. Would you prefer to purchase such a coating from the OEM Boat Builder or from an independent quality boat repair location? OEM $11 \%$
Repair Location
Eithe
$58 \%$

19. Do you currently order your charter boats from the OEM Builder with an antifouling paint or coating?
YES $16 \%$
NO
798

THANK YOU VERY MUCH ! ! 


\section{ASSOCIATED INDUSTRIES CORPORATION}

MANUFACTURER'S SAL.ES ENGINEERS MARKET RESEARCH \& SALES MANAGEMENT

June 13,1990

Dear Boat Yard Operations Manager:

AIC has been commissioned by an advanced coatings company to survey Boat Yard facilities as to the commercial feasibility of a "new" and "advanced" long-term antifouling system. The survey is part of a grant from the U.S. Department of Energy to analyze energy savings as it relates to the biofouling of recreational boat hulls.

The antifouling coating system will last in excess of ten years. It is not considered a toxic pollutant and would be approved as environmentally safe. The economic savings to the boat owner could be as much as $50 \%$ over current paint methods within a ten year period. The operating efficiencies that could be achieved would be the direct result of a continuously clean hull.

Your answers will be used for statistical tabulation only. Neither you nor your company will be identified. Your answers will provide vital information that will he critical in the determination of its commercialization.

Please complete and return this questionnaire as soon as you can. If you have any questions, please feel free to contact me directly. Your help in supplying this information is greatly appreciated.

$$
\text { Sincerely, }
$$

Gregory J. Gormley

Presiclent:

GJG/ef

Enclosure 
Boat Yard Operations Management Survey

\section{BACKGROUND INFORMA'TION}

Survey Participants Name

Title

1. Do you specify, recommend, or influence the purchase and use of antifouling materials for your Boat Yard operation?

YES $\quad 94 \%$ NO $6 \%$

2. What type of boats does your operation facilitate?

\begin{tabular}{ll}
$\frac{65}{4}$ & Recreational Sail \\
\hline$\frac{4}{8} \frac{1}{8} \frac{8}{8}$ & Commercial \\
Rnomalional Nowni
\end{tabular}

3. Which of the following services dues your racility provide?

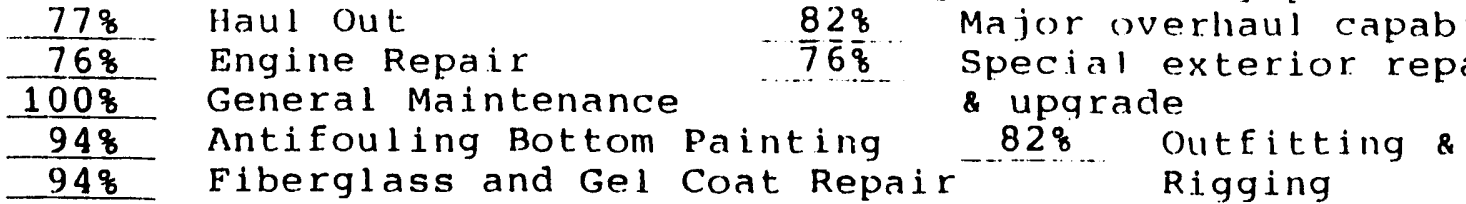

Other (Explain)

4. If your facility has a haul out capability, which types of equipment do you use?

\begin{tabular}{llll}
$\frac{188}{128}$ & $\begin{array}{l}\text { Rail System } \\
\text { Fork-1ift }\end{array}$ & 478 & Hoist and Travel Crane \\
\hline 68 & Stationary Crane & $18 \%$ & Dry Dock/Float Lock \\
\hline
\end{tabular}

5. What is the weight capacity of your haul out equipment? Gross weight (tons) Up to 25 ton - 18q 25 tont -598

6. What is the size capacity of your haul out equipment? Overall Length (feet) Up to 45 feet - 12845 feet -598

7. What is the average size (length) boat that you have in your facility?

Less than $30^{\prime} \quad 418^{\circ} \quad 30^{\prime}$ to $45^{\prime} \quad 478 \quad$ Greater than $45^{\circ} \quad 18 \%$

8. Does your facility specialize in any one type of customer or service?

YES $18 \%$ NO $82 \%$ Explain 


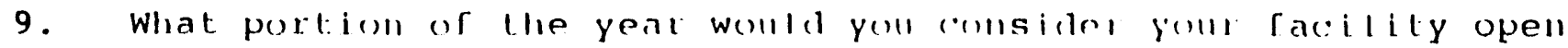

for hoat hottom repair and ant ifouling painting preparation?

$$
\begin{aligned}
& 82 \% \text { 12 montiss/year } \\
& 68 \text { months/year } \\
& \text { 68 Lese llinn o III) IIllis/yeitr }
\end{aligned}
$$

\section{PRODUCT SURVEY}

10. Would you consider boat bottom repair and preparalion for antifouling paints and coating a lina ior portion of your buat maintenance or repair business?

$$
\text { YES } 598 \text { NO } 35 \% \text { Finplain }
$$

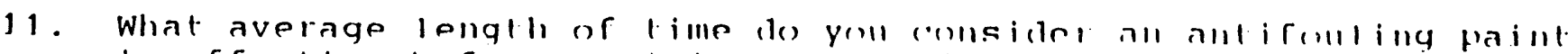

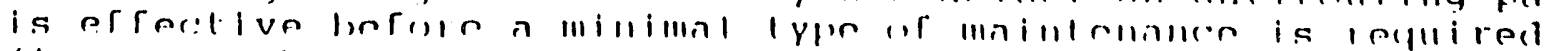

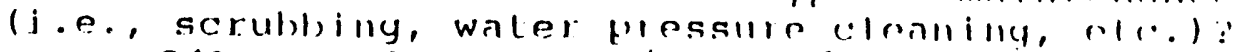

$$
\begin{array}{llll}
248 & 6 \text { months }+/- & 6 q & 1 \text { year } \\
-658 & 2 \text { years } & 0 q & \text { Greater llinh } 2 \text { years }
\end{array}
$$

12. Do you perceive long-term antifolling $(101$ years) as a benefit? YES 478 NO 418 FXVIain

13. Would an antifoulant coating with little or llo maintellance be an operational benefit to your organization?
YES
478
NO $\quad 358$
Fxplain

14. Would a $50 \%$ total cost savings to the boat owner in antifouling bottom maintenance (over a 10-year period) justify an up front cost of 2 to 3 times that of a normal paint application?

$$
\text { YES } \quad 418 \text { NO }
$$

15. Would your facility managenent consider purchasing in ranchise for the application of a long lerm anlifolling coating systell that would give you exclusive licensing righls hased on one of: the following:

If YES : $29 \%$

$\frac{100 \%}{208}$ Geographical area $\quad \frac{0}{0} \frac{8}{8}$ Registered hoat popoulation 208 Set number per state Facility capacity

$40 \%$ Financial stability

16. Would such a radical approach to antifouling maintenance benefit your organization as a franchise owner?
YES
188
NO 598
EXPI.NIN 

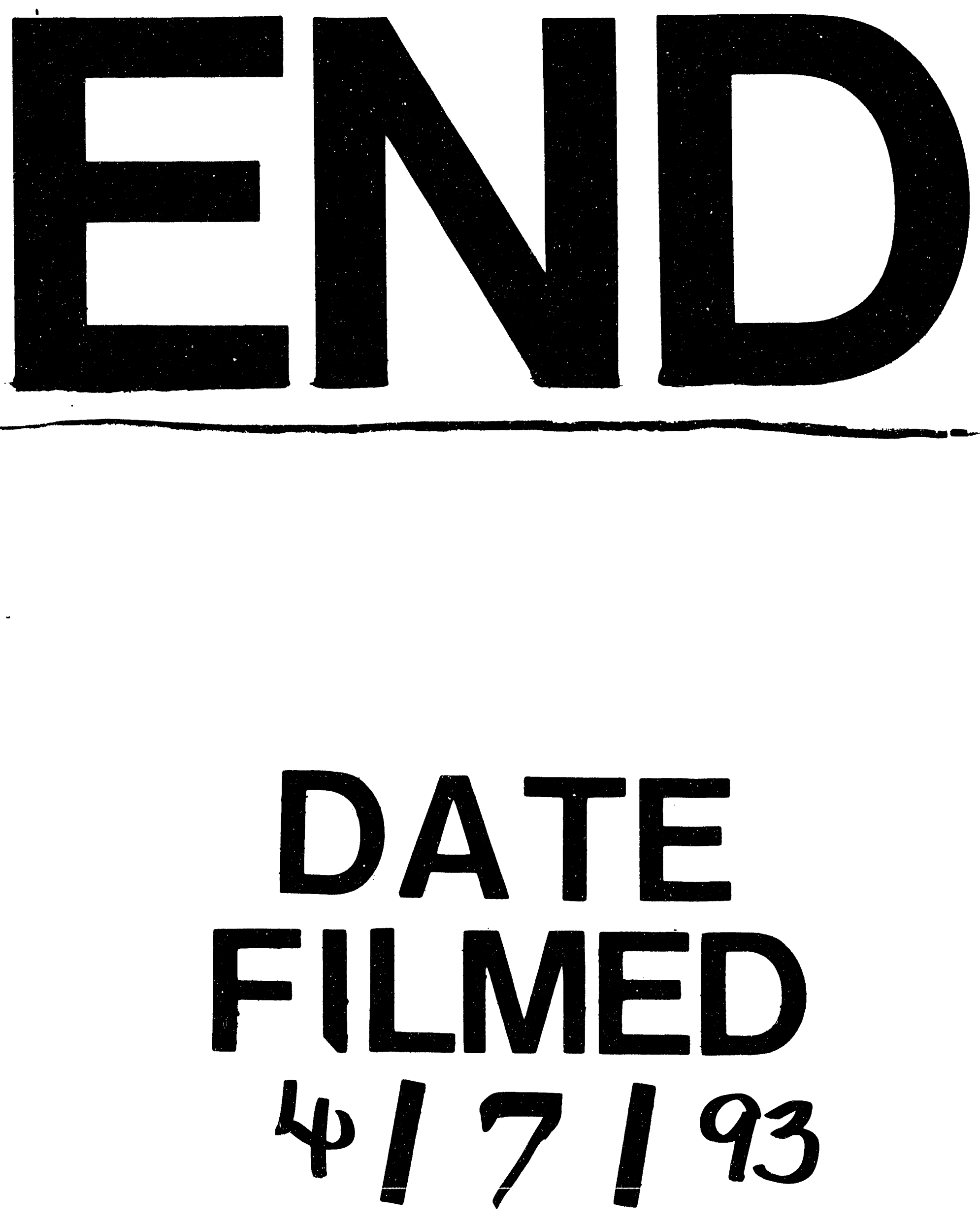
